\title{
Birlikte Soralım Birlikte Öğrenelim Tekniğinin Türkçe Öğretmeni Adaylarının Yazım ve Noktalama Başarısına Etkisi ${ }^{1}$
}

\author{
Aslı MADEN \\ Dr. Öğr. Gör., Giresun Üniversitesi Rektörlük Türk Dili Bölümü \\ asli.maden@giresun.edu.tr
}

\section{Özet}

Bu çalışmada, birlikte soralım birlikte öğrenelim tekniğinin Türkçe öğretmeni adaylarının yazım kuralları ve noktalama işaretlerinin kullanımına yönelik akademik başarıları üzerindeki etkisini araştırmak amaçlanmıştır. Araştırmada ön test-son test kontrol gruplu deneysel desen esas alınmıştır. Çalışma grubu, Giresun Üniversitesi Eğitim Fakültesi Türkçe Öğretmenliği lisans programında öğrenim gören 41 öğrenciden oluşmuştur. Deney $(n=20)$ ve kontrol grubu $(\mathrm{n}=21)$ random yöntemi ile düzenlenmiştir. Grupların yazım ve noktalama kurallarına yönelik akademik başarıları Yazım-Noktalama Başarı Testi (YNBT) ile toplanmıştır. Elde edilen veriler, SPSS 16 aracılığıyla Mann Whitney $U$ ve Wilcoxon $Z$ testleri kullanılarak analiz edilmiştir. Araştırma sonucunda, yazım kuralları ve noktalama işaretleri kullanımında deney ve kontrol grubu arasında akademik başarı yönünden birlikte soralım birlikte öğrenelim tekniği lehine anlamlı bir farkın olduğu görülmüştür.

Anahtar Sözcükler: Birlikte soralım birlikte öğrenelim tekniği, noktalama işaretleri, yazım, başarı.

\section{Effect of Ask and Learn Together Method on Turkish Pre-service Teachers' the Success to Use Spelling and Punctuation Rules}

\begin{abstract}
The aim of this study is to determine the effect of Ask and Learn Together method on success to use spelling and punctuation rules of Turkish pre-service teachers'. In the research, experimental design which is based on pre-test and post-test control group measurements has been used. The study groups of this research consist of 41 studests in the department of Turkish Language Education at Giresun University Faculty of Education. The experimental group $(n=20)$ and the control group $(n=21)$ were selected via simple random sampling. The study was conducted with Spelling and Punctuation Success Test pretest
\end{abstract}

\footnotetext{
${ }^{1}$ Makale Geliș/Kabul Tarihi:22.07.18/05.03.19

Kün.:MADEN, A . (2019). Birlikte Soralım Birlikte Öğrenelim Tekniğinin Türkçe Öğretmeni Adaylarının

Yazım ve Noktalama Başarısına Etkisi. Kahramanmaraş Sütçü İmam Üniversitesi Sosyal Bilimler Dergisi, 16 (1), 55-71. DOI: 10.33437/ksusbd.446629
} 
and posttest test on experimental and control groups' students. Mann Whitney U ve Wilcoxon $\mathrm{Z}$ statistics was used to analyze the data. As a result, Ask and Learn Together method are more influential on the academic success of the undergraduate students in using the spelling and punctuation rules in comparison to the traditional teaching method.

Keywords: Ask and learn together method, punctuation rules, spelling, succes, writing.

\section{GİRIŞ}

Yazma becerisi dil becerilerinin son halkası ve en gelişmiş olanıdır. Yazma becerisi ne kadar iyi olursa dil becerilerinin kullanımı da o denli gelişmiş olur. Yazma becerilerinin öğretilmesinde veya geliştirilmesinde, ilgi ve motivasyonun yüksek olmasına, öğrencilerin öz değerlendirme yapabilmelerine ve aynı şekilde eksiklerini düzeltilebilmelerine önem verilmelidir. Bu amaca ulaşmada "öğretmenler öğrencilere en yoğun öğretimden başlayarak giderek azalan bir destek sağlamalıdırlar" (Bryson, 2003: 1). Burada bahsedilen destek, öğrencinin kurallara uygun olarak kendisine anlatılan ve gösterilen işlemleri zamanla kendi kendine yapabilmesini sağlamaktadır. Söz yerinde ise, yazma konusunda öğretmenin yardımları ile öğrencinin bireysel hareket edebilmesine çalışılmalıdır. Öğretmenler, yazılı anlatım becerilerinin gelişimini öğrencilerin gereksinimlerine ve dersin amaçlarına göre destekleyebilirler. Bunun için kendisi örnek olabileceği gibi, uzmanların yani yazarların tecrübelerini model olarak anlatabilir. Yine öğrencilerine yazılarındaki hataları düzeltirken geribildirim vererek yol gösterebilirler. Öğretim sürecinde metin yazarken izleyeceği kuralları ve vermek istediği anlamı yansıtmada kullanması gereken işaretleri doğru seçebilmeyi, biçim ve içerik bakımından özgün ve değerli metinler oluşturmayı öğrenciye öğretebilecek yöntemleri kullanmak gereklidir. $\mathrm{Bu}$ açıdan öğretmenlerin yazma öğretimi sürecinde kullanılabilecek yöntem ve tekniklerle ilgili bilgi ve tecrübeye sahip olmaları, öğrencilerine uygun olan öğretim ortamını hazırlamalarını kolaylaştıracaktır.

Günümüz öğretim programları öğrenci merkezliliği temel alarak beraberinde bireysel farkl11ıkları önemseyen, öğrencinin öğrenme gereksinimlerine cevap verebilen ve aktif katılımı sağlayan strateji, yöntem ve teknikleri kullanmayı da zorunlu hâle getirmiştir. Ülkemizde de ana dili öğretiminde sözü edilen değişimler yaşanmış; öğrenci merkezli, bilgiyi yapılandıran, yaparak ve yaşayarak öğrenmeye ve öğrenme sürecinin bütüne önem veren bir öğretim anlayışı hâkim olmuştur. Bahsedilen anlayışa hizmet eden yöntemlerden biri de iş birlikli öğrenmedir. Bu yöntem; "öğrencilerin hem sınıf içi hem de sınıf dışı ortamlarda küçük karma gruplar oluşturularak ortak bir amaç doğrultusunda akademik bir konuda birbirlerinin öğrenmelerine yardımcı oldukları, öz güvenlerinin arttığı, iletişim, problem çözme ve eleştirel 
düşünme becerilerinin geliştiği, eğitim-öğretim sürecine aktif şekilde katıldıkları bir öğrenme yaklaşımı olarak tanımlanabilir" (Doymuş, Şimşek, Bayrakçeken 2004: 104).

İş birlikli öğrenme, öğrencilerin kendi öğrenmelerine öncelik vererek daha sonra diğerleri ile birlikte öğrenme düzeylerini yükseltmek için gruplar hâlinde performans sergiledikleri bir öğretim şeklidir (Johnson, Johnson ve Smith, 1991; Johnson ve Holubec, 1993: 6). İş birlikli öğrenme, motivasyonu artıran, öğrencilerin birbirlerine karşı saygılı ve hoşgörülü davranmasını teşvik eden, bu şekilde tartışabilmelerine olanak sağlayan ve eleştirel bakış açısı sergilemelerini kolaylaştıran bir yöntemdir (Davidson ve O'Leary, 1990: 33; Saban, 2004: 204; Senemoğlu, 2000: 501). Sözü edilen özellikleri öğrenme ortamına sokmak için iş birlikli öğrenmeyi sağlayacak farklı öğretim teknikleri bulunmaktadir.

\section{Birlikte Soralım Birlikte Öğrenelim Tekniği (BSBÖ)}

BSBÖ, iş birlikli öğrenmeyi sağlamak için başvurulabilecek bir küçük grupla öğretim tekniğidir. Tekniğin uygulama sürecinde, kolaya kaçma ve hazıra konmanın önüne geçmek için olumlu bağ kurma, grup ürünü ve etkileşim gibi temel ilkeler benimsenmektedir.

Birlikte soralım birlikte öğrenelim tekniği uygulanırken "grupların oluşturulması, konuyla ilgili materyalin okunması, öğrencilerin soru hazırlaması, grup sorusunun hazırlanması, grup sorularının gönderilmesi, grup sorularının yanıtlanması ve yanıtların sınıfa sunulması şeklinde aşamalar izlenir" (Açıkgöz, 1992: 64-73). İlgi çekmek ve güdülemek için öğrencilerin gruplara isim belirlemeleri, grup üyelerine süreci ilerletmek için farklı görevlerin (kaydedici, postacı, özetleyici, yazıc1, okuyucu, gözlemci ve sözcü gibi) verilmesi de tekniğin önemli yönlerindendir.

İş birlikli öğrenme teknikleri, bireyin dil becerilerini ve yazılı anlatım becerisini geliştirmek ve yazılı anlatım kurallarını öğretmek için kullanılabilecek etkili yollardandır. Nitekim yazılı anlatım becerilerinin doğru ve etkili biçimde kullanımını bir alışkanlık hâline getirme konusunda var olan uygulamaların dışında yeni yöntemlerin denenmesine de ihtiyaç olduğu söylenebilir. Zira ilkokuldan üniversiteye kadar yazılı anlatım ve yazma konusunda yeterince başarı sağlanamadığından yakınılmaktadır. $\mathrm{Bu}$ başarısızlığın temel sebeplerinden biri, yazma ve yazılı anlatım öğretiminde başvurulan yöntem ve tekniklerin yetersizliğidir. Alanyazınında yükseköğretime kadar tüm kademelerdeki öğrencilerin yazılı anlatım becerileri birçok araştırmaya konu olmuştur (Arıcı ve Ungan, 2008; Avc1, 2006; Cavkaytar, 2010; Demir, 2003; Kardaş, 2013a; Maden, 2011; Pekaz, 2007; Şahin ve diğerleri, 2011; Temizkan, 2001). Genel olarak, bu çalışmaların yazılı anlatım beceri düzeyine ilişkin tespitler ve öğretime yönelik öneriler sunduğu 
görülmektedir. Yazılı anlatım ile ilgili yapılan tespitlerde öne çıkan eksikliklerin en dikkat çekeni yazım ve noktalama kuralları ile ilgili yanlışlardır.

Bahsedilen tespitlere dayanarak yazılı anlatım becerilerinin geliştirilmesine yönelik çağdaş öğretim yöntem ve tekniklerini işe koşan çeşitli deneysel araştırmalar da yapılagelmiştir: Drama (Karateke, 2006), ipucu geri bildirim (Pekaz, 2007), iş birliği-gözlem (Erdiken, 1996), jigsaw (Maden, 2011b) ve birlikte öğrenme (Kardaş, 2013b) ile yazma becerilerini geliştirmeyi amaçlayan araştırmalar bunlara örnek gösterilebilir. Örnek olarak verilen araştırmaların amaçları ve ulaştıkları sonuçlar, yazılı anlatım aynı zamanda yazım ve noktalama kurallarının konusu ile ilgili ciddi bir problemin var olduğunu ortaya koymaktadır.

Alanyazınında iş birlikli öğrenme tekniklerinin öğrenci başarısına etkisi konusunda çok sayıda araştırma yapılmıştır. İş birlikli öğrenmenin Türkçe öğretimi ve yazılı anlatım konusundaki başarıyı artırdığını ortaya koyan araştırmalar burada örnek olarak gösterilebilir (Güngör, 2004; Kılıç, 2004: Maden, 2011a; Şahin, Maden, Kardaş ve Şahin, 2011; Şahin, 2010). Buna ek olarak iş birlikli öğrenme yönteminin motisvasyon ve tutum gibi duyuşsal özellikler üzerinde de olumlu etkisinin olduğu da belirlenmiştir (Altıparmak, 2001; Güngör ve Açıkgöz, 2006; Maden, Şahin ve Durukan, 2011; Özgiresun, 2005; Şahin, 2010; Varışoğlu, 2016). İş birlikli öğrenmenin dil öğretiminde uygulanmasına dair birçok örnek araştırmanın sunulabilmesi bu yöntemin "dil yeterliliği açısından hem homojen hem de heterojen gruplandırmaya imkân vermesi ve farklı özellik ve seviyeli gruplarda (siniflarda) yararlı olması" (Richards ve Rodgers, 2001: 198) ile açıklanabilir.

İş birlikli öğrenme tekniklerinin yazılı anlatım öğretiminde kullanımına dair örnek çalışmalar alanyazında yer alsa da BSBÖ'nün kullanımını örnekleyen bir çalışmaya rastlanamamaktadır. Bununla birlikte ilkokuldan itibaren yazım kuralları ve noktalama işaretlerinin kullanımı konusunda bir öğretime tabi olmalarına rağmen üniversite öğrencilerinin bu konuda hâlen ciddi eksikliklerinin olması anlamlı ve kalıcı öğrenmeler sağlayacak yeni öğretim yollarına ihtiyaç olduğunun bir işaretidir. Bu eksikliğin giderilmesinde önemli olan bir diğer husus ise, yazma öğretimi yapacak öğretmenlerin yazılı anlatım konusundaki alan bilgisi ve formasyon yeterlilikleridir. Nitekim öğretmenlerin etkili ve doğru yazma becerisine sahip olması ve yazma sürecini tanıması, yazma sürecinde doğru stratejileri kullanmalarına yardımcı olacaktır (Kapka ve Oberman, 2001). Ancak üniversite düzeyinde öğrenim gören ve gelecekte bahse konu olan yazım ve noktalama konusunu öğretecek olan öğretmen adaylarının dahi yazılı anlatım düzeylerinin beklenilenden çok uzak olduğu çeşitli araştırmalarda ortaya konulmuştur (Babacan, 2003; Bağc1, 2007; Karabuğa, 2011; Şahin ve Topuzkanamış, 2008; Temizkan, 2008). Sözü edilen durum yeni nesillere kurallara uygun biçimde yazılı anlatım alışkanlığı 
kazandıracak ve örnek olacak öğretmen adaylarının bu konuda yetiştirilmesine önem ve öncelik verilmesini zorunlu kılmaktadır. Bu bağlamda, kolaya kaçma ve hazıra konmanın önüne geçmek için olumlu bağ kurma, grup ürünü, bireyselgrup değerlendirme ve etkileşim gibi yönler ile öğrenciye birlikte başarma hissini tattıran BSBÖ tekniğinin yazılı anlatım kurallarının öğretiminde kullanılmasının fayda sağlayacağı düşünülmektedir.

Bahsedilen gerekçelerden hareketle bu çalışmada, iş birlikli öğrenme tekniklerinden Birlikte Soralım Birlikte Öğrenelim tekniğinin Türkçe öğretmen adaylarının yazım kuralları ve noktalama işaretlerini kullanma konusundaki akademik başarıları üzerindeki etkisini belirlemek amaçlanmıştır.

\section{YÖNTEM}

\section{Araştırma Modeli}

Araştırmada Türkçe öğretmeni adaylarının yazım kuralları ve noktalama işaretleri kullanımı konusundaki başarı bağımlı değişken, deney grubunda uygulanan Birlikte Soralım Birlikte Öğrenelim tekniği ile kontrol grubunda uygulanan geleneksel öğretim yöntemi ise bağımsız değişken olarak belirlenmiştir. Araştırma, iki farklı yöntemin etkisi karşılaştırılacağından araştırma deneysel nitelik taşımaktadır. Bu nedenle araştırmada 'ön test - son test kontrol gruplu deneysel desen' kullanılmıştır. "Ön test-son test kontrol gruplu desen, deneysel işlemin bağımlı değişken üzerindeki etkisinin test edilmesiyle ilgili olarak araştırmacıya yüksek bir istatistiksel güç sağlayan, elde edilen bulguların neden sonuç bağlamında yorumlanmasına olanak veren ve davranış bilimlerinde sıklıkla kullanılan güçlü bir desendir" (Büyüköztürk, 2001: 27).

\section{Çalışma Grubu}

Araştırmanın çalışma grubu, Giresun Üniversitesi Türkçe Öğretmenliği lisans programında öğrenim gören 41 öğrenciden oluşmuştur. Çalışma grubu, ön test sonuçları anlamlı farklılık göstermediğinden yansız atanmıştır. Birlikte Soralım Birlikte Öğrenelim (BSBÖ) tekniğinin uygulandığı deney grubu 20, geleneksel öğretimin uygulandığı kontrol grubu 21 öğrenciden oluşmuştur.

Tablo 1. Deney ve kontrol gruplarinin ön test sonuçlart

\begin{tabular}{lcccccccc}
\hline & Gruplar & $\mathbf{N}$ & $\begin{array}{c}\text { Arit. } \\
\text { Ort. }\end{array}$ & Ss. & $\begin{array}{c}\text { Fark Sıra } \\
\text { Ort. }\end{array}$ & $\begin{array}{c}\text { Sira } \\
\text { Top. }\end{array}$ & U & p \\
\hline \multirow{2}{*}{$\begin{array}{l}\text { Ön } \\
\text { test }\end{array}$} & Deney & 20 & 9,950 & 2,212 & 18,65 & 373,00 & & \\
\cline { 2 - 9 } & Kontrol & 21 & 10,762 & 1,947 & 23,24 & 488,000 & 0.213 \\
\hline
\end{tabular}




\section{Veri Toplama Araçları}

Yazım -Noktalama Başarı Testi (YNBT)

Araştırmada öğrencilerin akademik başarılarına ait veriler "Yazım ve Noktalama Başarı Testi" ile toplanmıştır. YNBT, araştırmacı tarafından geçmiş yıllara ait ulusal sınav sorularından seçilmiştir.

Başarı testinin geliştirmesinde ilk olarak 42 maddelik bir soru havuzu oluşturulmuş ve Türkçe eğitimi alanından $(n=3)$ ve ölçme değerlendirme alanından $(n=1)$ uzmanların görüşleri alınarak soru sayısı 28 'e düşürülmüştür. Taslak test 70 Türkçe öğretmeni adayı üzerinde pilot olarak uygulanmıştır. Pilot uygulama sonrasında, testteki 8 maddenin düşük güvenirliğe sahip olduğu görülmüş ve ölçekten çıkarılmıştır. Bu işlemler sonrası soru sayısı 20 maddeye inen başarı testinin madde güçlük değerlerinin 0,20 ile 0,83 arasında olduğu belirlenmiştir. Bunların yanında, testin KR-20 formülü ile iç tutarlık katsayısı 0,88 olarak hesaplanmıştır. Testteki her soru 1 puan üzerinden değerlendirilmiştir. Geliştirilen YNBT deney ve kontrol gruplarına ön ve son test olarak uygulanmıştır.

Tablo 2. Uygulama süreci

\begin{tabular}{cccc}
\hline Ön Test & Grup Adı & Uygulanan Teknik & Son test \\
\hline \multirow{2}{*}{ YNBT } & Deney & $\begin{array}{c}\text { Birlikte Soralım Birlikte Öğrenelim } \\
\text { (BSBÖ) }\end{array}$ & \multirow{2}{*}{ YNBT } \\
\cline { 2 - 3 } & Kontrol & Geleneksel Öğretim & \\
\hline
\end{tabular}

Çalışmada (iş birlikli öğrenme tekniklerinden Birlikte Soralım Birlikte Ögrenelim (BSBÖ)'in uygulandığı) deney grubu ile (geleneksel öğretim yönteminin uygulandığı) kontrol grubunun yazım kuralları ve noktalama işaretlerine konusundaki akademik başarıları arasında anlamlı bir farklılı̆̆ın olup olmadığını belirlemek için, YNBT çalışma grubuna ön test olarak uygulanmıştır. YNBT elde edilen veriler 1şığında, çalışma grubu arasında anlamlı bir farkın olmadığ tespit edilmiş, deney ve kontrol grupları random (yansız) atama tekniği ile oluşturulmuştur.

\section{Uygulama Süreci}

Araştırma kapsamında, yazım kuralları ve noktalama işaretlerinin kullanımı konusunun teori ve uygulamada geçerli olan kurallarına yönelik etkinlikler Birlikte Soralım Birlikte Öğrenelim (BSBÖ) tekniği ve geleneksel 
öğretim yöntemi ile araştırmacının uygulama planı doğrultusunda dersin sorumlusu tarafindan yürütülmüştür. Yazılı anlatımda uyulması gereken kurallar ve noktalama işaretleri konusu, Türk Dil Kurumu'nun Yazım Kılavuzu ve ilgili alanyazın incelenerek belirli başlıklara ayrılmış ve bu başlıklara göre çalışma yaprağı ve sorular hazırlanmıştır. Konu çalışma (deney ve kontrol) grubunda, haftada 2 ders saati olmak üzere bir ay boyunca dersin sorumlusu tarafindan ilgili yöntem ve teknik kullanılarak işlenmiştir.

\section{Deney grubuna yönelik işlemler:}

Deney sürecinin ilk haftasında ön testler uygulanmıştır. Deney grubundaki öğrencilere, önce Birlikte Soralım Birlikte Ögrrenelim tekniğinin gerektirdiği grup çalışmaları hakkında bilgi verilmiştir.

Deney grubunda uygulanan BSBÖ tekniğinin uygulama basamakları aşağıda verilmiştir.

1) BSBÖ tekniğine göre, öğrenci özellikleri de önemsenerek heterojen gruplar oluşturulmuştur. Öğrencilerin gruplara seçilmesi dersin hocası tarafından yapılmıştır. Gruplara cinsiyet ve başarı durumlarına göre eşit sayıda öğrenci seçilmesine özen gösterilmiştir.

Sınıf mevcudu 20 olduğu için 4 kişiden oluşan 5 grup oluşturulmuştur. Öğrencilerden gruplarına bir ad bulmaları istenmiştir. 1. Grup Dedektifler 2.Grup Yarışçılar. 3. grup Bitirimler. 4. Grup Akıllılar. 5. Grup Şovmenler şeklinde ad almıştır.

Öğrenciler sınıfın belirli kısımlarına gruplar hâlinde yerleştirilmiştir.

BSBÖ tekniği ile öğretiminin ilk basamağı, ders materyalinin öğretmenin yönlendirmesiyle okunması ve üzerinde düşünülmesidir. Buna uygun olarak, yazım kuralları ve işaretlerle ilgili örnek bir metin okunmuştur. Ardından hoca tarafından hazırlanan yazım kuralları ve noktalama işaretlerinin kullanımına yönelik çalışma yaprakları öğrencilere dağıtılmıştır. Öğrenciler kendi örneklerini önce grup içinde çözmüşlerdir. Anlaşılmayan kısımlar için gruplar arasında örneklendirmeler yapılmıştır. Sonra sınıfa sunmuşlardır. Dersin sorumlusu da daha önceki genel sınavlarda sorulmuş birkaç soruyu öğrencilere yöneltmiştir. Cevabı sınıfla birlikte bulmaları için yönlendirmelerde bulunulmuştur.

2) İkinci hafta konu ile ilgili öğrenciler sorular hazırlamışlardır. Yazılı anlatımda uyulması gereken kurallar ve noktalama işaretleri ile ilgili sorular okunan metne göre hazırlanmıştır. Öğrenciler hazırladıkları soruları bir karta yazmışlardır.

3) Üçüncü hafta öğrenciler sorularını kartlara yazmışlar, sonra grup üyeleri bir araya gelerek konu ile ilgili birlikte grup sorusu oluşturmuşlardır. $\mathrm{Bu}$ sorunun ya yeniden grup hâlinde oluşturulacağı ya da öğrenci soruları arasından 
da seçilebileceği gruplara hoca tarafindan söylenmiştir. Bu aşama, grup içinde iş birliği sağlanacağ 1 için çok önemlidir. Grup sorusu oluştururken hoca tarafından öğrencilere katılımı destekleyecek roller verilmiştir. Grupça hazırlanmış yazılı anlatım soruları postacı aracılığıyla başka gruplara gönderilir. $\mathrm{Bu}$ şekilde her gruba bir soru dağıttılmış olur. Gruplar iş birliği içinde bu soruları cevaplamıştır. Grupların seçtikleri sözcüler yanıtları sınıfa sunmuştur.

Gruplar hazırlanan soruları cevaplamış ve sözcüler doğru yanıtları sınıfa sunmuştur. Bunun ardından gruplar derste yaptıklarını birlikte değerlendirmiş, zamanın yetersiz olduğu konusunda birleşmişlerdir. Dersin hocası yazım kuralları ve noktalama işaretleri konusu kapsamında öğrenciler tarafından hazırlanan sorulardan bazılarını sınıfa yöneltmiş yanıtları birlikte değerlendirilmiştir.

Dersin sorumlusu sorduğu sorularla yazım kuralları ve noktalama işaretlerinin kullanımıyla ilgili konuların öğrenilip öğrenilmediğini sınamıştır. Yeterli görerek grup çalışmalarını sonlandırmıştır. Grupların genel olarak konuyu kavrama, sentez ve uygulama düzeyinde öğrendikleri görülmüş ve son test uygulamasına geçilmiştir.

\section{Kontrol grubuna yönelik işlemler:}

Kontrol grubunda yazım kuralları ve noktalama işaretleri konusunun öğretimi geleneksel öğretim yöntemi ile araştırmacının uygulama planına uygun olarak dersin sorumlusu tarafından anlatılmıştır. Geleneksel öğretim yöntemiyle işlenecek dersler, araştırmacı ile dersin hocası tarafindan öğrencilerin kazanması gereken beceriler dikkate alınarak planlanmıştır. Ön testler birinci hafta uygulanmış ve daha sonra dört hafta süresince yazım ve noktalama konusuna yönelik öğretim etkinlikleri dersin hocası tarafindan yürütülmüştür. Geleneksel öğretim "öğretmen merkezli, öğretmenin bilgiyi öğrenenlere aktarma sürecini içeren ve sözlü anlatıma ağırlık veren yöntem" olarak tanımlanmaktadır (Demirel, 2004: 72). Bu doğrultuda, derslerde dersin hocası plana uyarak konuyla ilgili kuralları düz anlatım ile aktarmış ve örneklendirmiştir. Dersin sonunda o günkü konu özetlenmiştir. Soru cevap tekniği ile öğrenciler sınanmıştır. Geri bildirimler verilmiş, dersler tamamlanmıştır.

Uygulama her iki grupta da plana uygun olarak dersin sorumlusu tarafından sürdürülmüsstür. Uygulama sonrasında deney (Birlikte Soralım Birlikte Öğrenelim) ve kontrol (Geleneksel Öğretim) grubuna YNBT son test olarak uygulanmıştır.

\section{Verilerin Analizi}

Deney ve kontrol gruplarının ön test ve son testlerinden elde edilen veriler SPSS paket programı ile analiz edilmiştir. 
Deney ve kontrol grubundaki öğrencilerin yazım kuralları ve noktalama işaretleri konusundaki akademik başarılarına ilişkin verilerin analizinde hangi istatistik tekniklerinin kullanılacağını belirlemek için verilerin dağılım normalliği incelenmiştir. Örneklem büyüklüğüne bağlı olarak Shapiro Wilks veya Kolmogorov Simirnov testleri kullanılarak verilerin normalliği test edilmektedir. Çalışma grubundaki öğrenci sayısı 41 olduğu için Shapiro-Wilks testi temel alınmıştır.

Tablo 3. Shapiro-Wilks testine göre veri dă̆gllımı

\begin{tabular}{lccc}
\hline \multicolumn{4}{c}{ Shapiro-Wilks } \\
\hline Değer & sd & $\mathrm{p}$ \\
\hline YNBT & 0,988 & 41 & 0,006 \\
\hline
\end{tabular}

Shapiro-Wilks analizi sonucunda yazım ve noktalama başarısına ilişkin verilerin normal dağılım göstermediği görülmüsstür $(p<0,05)$. Bu doğrultuda verilerin analizinde, örneklem sayısının 50'nin altında olması ve verilerin normal dağılım göstermemesinden dolayı non-parametrik analiz yöntemlerinden Mann Whitney $U$ ve Wilcoxon $Z$ testleri kullanılmıştır. Araştırmada, anlamlılık seviyesi $\mathrm{p}<0,05$ olarak belirlenmiştir.

\section{BULGULAR}

Yazım Kuralları ve Noktalama İşaretleri Başarısına Yönelik Bulgular

Tablo 4. Deney ve kontrol gruplarının ön test ve son test ortalamalarl

\begin{tabular}{|c|c|c|c|c|c|c|c|c|c|}
\hline & & $\mathbf{N}$ & $\begin{array}{l}\text { Arit. } \\
\text { Ort. }\end{array}$ & S.Sapma & & $\begin{array}{l}\text { Sira } \\
\text { Ort. }\end{array}$ & $\begin{array}{c}\text { Sira } \\
\text { Toplamı }\end{array}$ & $\mathbf{Z}$ & $\mathbf{p}^{*}$ \\
\hline \multirow{2}{*}{ Deney } & $\begin{array}{l}\text { Ön } \\
\text { Test }\end{array}$ & \multirow{2}{*}{20} & 9,950 & 2,212 & $\begin{array}{l}\text { Negatif } \\
\text { Sira }\end{array}$ & 10,50 & 210,00 & \multirow{2}{*}{3.927} & \multirow{2}{*}{0.000} \\
\hline & $\begin{array}{l}\text { Son } \\
\text { Test }\end{array}$ & & 19,350 & 1,386 & $\begin{array}{l}\text { Pozitif } \\
\text { Sira }\end{array}$ &, 00 &, 00 & & \\
\hline Kontrol & $\begin{array}{l}\text { Ön } \\
\text { Test }\end{array}$ & 21 & 10,762 & 1,947 & $\begin{array}{l}\text { Negatif } \\
\text { Sira }\end{array}$ & 11,00 & 231,00 & 4.051 & 0.000 \\
\hline
\end{tabular}

*0.05 Anlamlılık Düzeyi 


\begin{tabular}{|c|c|c|c|c|c|}
\hline $\begin{array}{l}\text { Son } \\
\text { Test }\end{array}$ & 16,667 & 2,265 & $\begin{array}{c}\text { Pozitif } \\
\text { Sira }\end{array}$ & ,00 & ,00 \\
\hline
\end{tabular}

Tablo 4'e göre, deney ve kontrol grubundaki öğrencilerin yazım kuralları ve noktalama işaretleri konusundaki başarıları son testte artış göstermiştir.

Deney grubundaki öğrencilerin YNBT ortalamaları ön testte $\bar{x}=9,950$ iken, son testte ortalamalarının $\bar{x}=19,350$ 'e yükseldiği tespit edilmiştir. Bu durum deney grubunda uygulanan tekniğinin yazım ve noktalama işaretleri konusunun öğretiminde etkisinin olduğunu göstermektedir. Aynı şekilde kontrol grubundaki öğrencilerin de YNBT ön test ortalamasının $\bar{x}=10,762$, son test ortalamasının ise $\bar{x}=16,667$ olduğu tespit edilmiştir. $\mathrm{Bu}$ bulgu, kontrol grubunda uygulanan yöntemin de yazım ve noktalama konusunun öğretiminde belirli düzeyde etkisinin olduğunu göstermektedir. Diğer taraftan elde edilen veriler üzerinde yapılan $Z$ testi istatistiğine göre, deney grubundaki öğrencilerin ön ve son test ortalamaları arasinda anlamlı bir farklılık bulunmaktadır (Z= $3,927, \mathrm{p}<0,05)$. Kontrol grubundaki öğrencilerin ön-son test başarı ortalamaları arasında da $(Z=4,051, p<0,05)$ ayn durum söz konusudur. Dolayısıyla hem deney hem de kontrol grubunda yazım ve noktalama kurallarının öğretiminde uygulanan yöntem / tekniğin başarı üzerinde etkisinin olduğu söylenebilir.

\section{Deney ve Kontrol Grubu Son Test Bulguları}

Tablo 5. Deney ve kontrol grubunun son test başarılarının analizi

\begin{tabular}{|c|c|c|c|c|c|c|c|c|}
\hline & Gruplar & $\mathbf{N}$ & $\begin{array}{l}\text { Arit. } \\
\text { Ort. }\end{array}$ & S.Sapma & $\begin{array}{c}\text { Fark Sira } \\
\text { Ort. }\end{array}$ & $\begin{array}{c}\text { Sira } \\
\text { Toplamı }\end{array}$ & $\mathbf{U}$ & $\mathbf{p}$ \\
\hline \multirow{2}{*}{$\begin{array}{l}\text { Son } \\
\text { test }\end{array}$} & Deney & 20 & 19,350 & 1,386 & 28,08 & 561,50 & \multirow{2}{*}{68,500} & \multirow{2}{*}{0.000} \\
\hline & Kontrol & 21 & 16,667 & 2,265 & 14,26 & 299,50 & & \\
\hline
\end{tabular}

Deney ve kontrol grubundaki öğrencilerin ön ve son test ortalamalarına göre iki grupta da uygulanan yöntem ve tekniğin başarı üzerinde etkili olduğu görülmüştür. Ancak son test ortalamaları üzerinde yapılan U testi istatistiğine göre; deney grubunun 19,35 olan son test ortalamas1 ile kontrol grubunun 16,6 olan son test ortalamaları arasında anlamlı düzeyde farklılık tespit edilmiştir $(\mathrm{U}=68,500, \mathrm{p}<0,01)$. Diğer bir ifade ile deney grubunda uygulanan iş birlikli 
öğrenme tekniklerinden Birlikte Soralım Birlikte Öğrenelim'in yazım ve noktalama kuralları öğretiminde geleneksel öğretim yöntemine göre daha etkili olduğu söylenebilir.

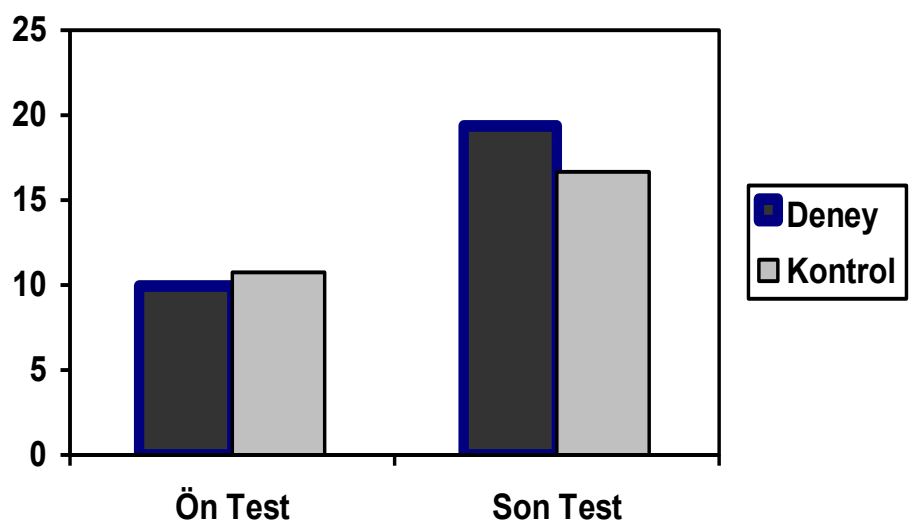

Grafik 1. Deney ve kontrol gruplarının ön-son test ortalamaları

Grafik 1'de de görüldüğü üzere, deney ve kontrol gruplarının ön test başarıları birbirine çok yakın iken son testte iki grubun yazım ve noktalama kuralları başarısı arasında belirgin bir farklılığın oluştuğu görülmektedir. Buradan hareketle, yazım ve noktalama başarısı üzerinde deney grubunda uygulanan Birlikte Soralım Birlikte Öğrenelim tekniği lehine bir farkın olduğu anlaşılmaktadır.

\section{TARTIŞMA VE SONUÇ}

Türkçe öğretmeni adaylarının yazım kuralları ve noktalama işaretlerinin kullanımı konusundaki akademik başarıları üzerinde iki farklı öğretim yönteminin etkisinin araştırıldığı bu çalışmada Birlikte Soralım Birlikte Öğrenelim lehine anlamlı sonuçlara ulaşılmıştır.

BSBÖ tekniğinin yazım kuralları ve noktalama işaretlerine yönelik akademik başarıya etkisi için ulaşılan bulgular ile alanyazındaki bazı çalışmaların sonuçları arasında benzerlikler bulunmaktadır (Hertz-Lazarowitz ve diğ., 1997; Stevens, 2003; Şahin, 2010). Sevim ve Varışoğlu'nun (2014) iş birlikli öğrenme tekniklerinden akademik çelişkinin Türkçe öğretmeni adaylarının kavram öğrenme başarıları üzerine olumlu etkisinin olduğuna dair ulaştıkları sonuçlar araştırma bulgularını temellendirmektedir. Veenman ve arkadaşlarının (2002) iş birlikli öğrenmenin öğretmen eğitiminde akademik başarıyı desteklediğine dair açıklamaları da ulaşılan sonuçlarla örtüşmektedir. Yine Kardaş'ın (2013) birlikte öğrenme tekniğgi ile yürüttüğü deneysel çalışmada da iş birlikli öğrenmenin öğretmen adaylarının yazılı anlatım 
konusundaki başarıları üzerinde daha etkili olduğu tespit edilmiştir. Karakoyun (2010) da noktalama işaretlerinin öğretiminde iş birlikli öğrenme tekniklerinin geleneksel öğretimine göre daha etkili olduğunu ortaya koymuştur. Aynı şekilde Syh-Jong'un (2007) iş birlikli gruplarda öğrencilerin konuşma ve yazma becerilerini kendi kendilerine yapılandırmalarının kolaylaştığına dair tespiti de bulgular ile örtüşmektedir. Buna karşın Maden (2011b) tarafindan yapılmış olan araştırmada Jigsaw I tekniğinin Türkçe öğretmeni adaylarının yazılı anlatım başarıları üzerinde anlamlı bir farklılık oluşturmadığı görülmüştür. Bunlara ek olarak iş birlikli öğrenme tekniklerinden BSBÖ'nün akademik başarı üzerindeki etkisine yönelik ulaşılan bulgular alanyazındaki bazı çalışmaların sonuçlarını desteklemektedir (Altıparmak, 2001; Chen, 2004; Gökdağ, 2004; Johnson, Johnson ve Stanne 2000; Melser, 1999, Özer, 1999; Özkal, 2000; Salman, 2005; Sarıtaş, 2002; Sülün, Tekin ve Tekin 2005; Tarım ve Artut, 2004; Yaman, 1999).

Elde edilen bulgularda, deney grubunun ön ve son test ortalamaları arasında $Z=3,927, p<0,01$ düzeyinde, kontrol grubunun ön ve son test ortalamaları arasında ise $Z=4,051, \mathrm{p}<0,01$ düzeyinde anlamlı bir farklılığın olduğu tespit edilmiştir. Bulgulara ek olarak, deney ve kontrol gruplarının ön test ortalamaları arasında ( $U=163.500 \mathrm{p}>0.05)$ anlamlı bir farklılığın olmadığ ancak son test ortalamaları (Deney $\bar{x}=19,350$, Kontrol $\bar{x}=16,667$ ) arasinda $\mathrm{U}=68.500, \mathrm{p}<0.01$ anlamlılık düzeyinde deney grubu lehine anlamlı bir fark olduğu görülmüş̧ür.

Bulgulardan hareketle, Birlikte Soralım Birlikte Öğrenelim tekniğinin ve geleneksel öğretim yönteminin yazım kurallarını ve noktalama işaretlerini kullanma becerilerinin öğretiminde etkili olduğu ancak deney grubunda kullanılan BSBÖ tekniğinin başarı üzerinde daha etkili olduğu söylenebilir.

\section{Öneriler}

Araştırmada ulaşılan sonuçlardan hareketle öğretmen adayları ile birlikte diğer üniversite öğrencilerinin yazım kuralları ve noktalama işaretleri başarıları üzerinde de BSBÖ ve diğer iş birlikli öğretim tekniklerinin kullanımının katkı sunacağı düşünülmektedir. Ayrıca, öğretmen eğitimi müfredatlarının ve öğretim materyallerinin hazırlanmasında iş birlikli eğitim uygulamaları dikkate alınmalıdır. Bunlar birlikte;

1) BSBÖ tekniği diğer dil becerilerinin öğretiminde kullanılabilir.

2) BSBÖ, farklı yaş ve eğitim seviyelerinde öğrenciler üzerinde başarı, tutum ve görüşlerini belirlemek amaciyla uygulanabilir.

3) İlk ve ortaöğretim düzeyinde görev yapan öğretmenlerin BSBÖ tekniğinin kullanımına dair görüşleri tespit edilebilir. 


\section{KAYNAKÇA}

Açıkgöz, K. (1992). İş birlikli öğrenme kuram-araştırma-uygulama. Malatya: Uğurel Matbaası.

Altıparmak, M. (2001). Biyoloji öğretiminde işbirlikli öğrenme yönteminin laboratuara yönelik tutum ve başarı üzerine etkisi. Yayımlanmamış yüksek lisans tezi, Dokuz Eylül Üniversitesi, İzmir.

Arıc1, A. F. ve Ungan, S. (2008). İlköğgretim ikinci kademe öğrencilerinin yazılı anlatım çalışmalarının bazı yönlerden değerlendirilmesi. Dumlupınar Üniversitesi Sosyal Bilimler Dergisi, 20, 317-327

Avcı, E. (2006). İlköğretim 8. sınıf öğrencilerinin yaptıkları yazılı anlatım yanlışlarının incelenmesi (Muğla İli Örneği). Yayımlanmamış yüksek lisans tezi, Ankara Üniversitesi. Sosyal Bilimler Enstitüsü, Ankara

Babacan, M. (2003). Ortaöğretimdeki Türk dili ve edebiyatı öğretiminin eğitim fakültesi Türkçe eğitimi bölümü öğrencilerinin yazılı anlatım dersi sınav ve ödevleri çerçevesinde durumu. Ankara Üniversitesi TÖMER Dil Dergisi, 122, 61-75.

Bağcı, H. (2007). Türkçe öğretmeni adaylarının yazılı anlatım derslerine yönelik tutumları ile yazma becerileri üzerine bir araştırma. Yayımlanmamış doktora tezi. Gazi Üniversitesi, Ankara.

Bryson, F. K. (2003). An examination of two methods of delivering writing instruction to fourth grade students. Unpublished master thesis, Texas Woman's University, Texas.

Büyüköztürk, S. (2001). Deneysel desenler. Ankara: PegemA Yayıncılık.

Cavkaytar, S. (2010). İlköğretimde yazılı anlatım becerilerinin geliştirilmesinde yazma süreci modelinden yararlanma. Uluslararası Sosyal Araştırmalar Dergisi, 3(10), 133-139.

Chen, M. L. (2004). A study of the effects of cooperative learning strategies on student achievement in english as a foreign language in a taiwan college. Dissertation Doctoral Thesis. Spalding University, Taiwan.

Davidson, N. \& O'Leary (1990). Introduction from cooperative learning in mathematics. New York: Addison- Wesley.

Demir, G. K. (2003). İlköğretim birinci ve ikinci kademe öğrencilerinin yazım hataları ve öğretmen görüșleri. Yayımlanmamış yüksek lisans tezi, Gazi Üniversitesi Eğitim Bilimleri Enstitüsü, Ankara.

Demirel, Ö. (2004). Öğretme sanatı: öğretimde planlama ve değerlendirme. Ankara: PegemA Yayıncilık.

Doymuş, K., Şimşek, Ü., ve Bayrakçeken, S., (2004). İşbirlikçi öğrenme yönteminin fen bilgisi dersinde akademik başarı ve tutuma etkisi, Türk Fen Ë̆itimi Dergisi, 1(2), 103-115.

Erdiken, B. (1996). Anadolu üniversitesi İçem lise düzeyindeki işitme engelli öğrencilerin yazılı anlatım becerilerinin geliştirilmesinde işbirliğ 
gözlem yöntemi ile anlatım yönteminin karşılaştırılması. Yayınlanmamış doktora tezi, Anadolu Üniversitesi Sosyal Bilimler Enstitüsü, Eskişehir

Gökdağ, M. (2004). Sosyal bilgiler öğretiminde iş birlikli öğrenme, öğrenme stilleri, akademik bașarı ve cinsiyet ilişkileri. Yayımlanmamış Doktora Tezi. Dokuz Eylül Üniversitesi Eğitim Bilimleri Enstitüsü, İzmir.

Güngör, A. ve Ün Açıkgöz, K. (2006). İşbirlikli öğrenme yönteminin okuduğunu anlama stratejilerinin kullanımı ve okumaya yönelik tutum üzerindeki etkiler. Kuram ve Uygulamada Eğitim Yönetimi Dergisi, 48, 481-502.

Hertz-Lazarowitz, R., Calderon, M., Ivory, G. \& Slavin, R.E. (1997). Effects of bilingual cooperative integrated reading and composition on students transitioning from spanish to english reading, center for research on the education of students placed at risk (CRESPAR).http://www.csos.jhu.edu/crespar/techreports/report10.pdf' den adresinde 26.05.2008 tarihinde erişilmiştir.

Johnson, D. W., Johnson, R. T. \& Stanne M.B. (2000). Cooperative learning methotds: a meta analysis. Minnesota: University of Minnesota Cooperative Learning Center.

Johnson, D.W., Johnson, R.T. \& Holubec, E.J., (1993). Cooperative learning in the classroom cooperation in the classroom. Alexandria, VA: Association for Supervision and Curriculum Development, Minnesota.

Johnson, D.W., Johnson, R.T. \& Smith, K. (1991). Active learning: cooperation in the college classroom. Edina Minn: Interaction Book Company.

Kapka, D., \& Oberman, D. A. (2001). Improving student writing skills through the modeling of the writing process. Research Project, Saint Xavier University and SkyLight Professional Development Field-Based Masters Program. ERIC ED 453536.

Karabuğa, H. (2011). Türkçe öğretmeni adaylarının yazılı anlatım çalışmalarında noktalama işaretlerini ve yazım kurallarını kullanabilme düzeyleri. Yayımlanmamış yüksek lisans tezi. Abant İzzet Baysal Üniversitesi, Sosyal Bilimler Enstitüsü, Bolu.

Karakoyun, M. E. (2010) İlköğretim 5. sınıf öğrencilerine noktalama işaretlerinin öğretiminde işbirlikli öğrenme tekniklerinden Jigsaw I'in akademik başarıya etkisi. Yayımlanmamış yüksek lisans tezi, Atatürk Üniversitesi, Sosyal Bilimler Enstitüsü, Erzurum

Karateke, E. (2006). Yaratıcı dramanın ilköğretim ikinci kademede 6. sınıf öğrencilerinin yazılı anlatım becerilerine olan etkisi. Yayınlanmamış yüksek lisans tezi, Mustafa Kemal Üniversitesi Sosyal Bilimler Enstitüsü, Hatay. 
Kardaş, M.N. (2013a). İş birlikli öğrenme yönteminin sınıf öğretmeni adaylarının yazılı anlatım becerilerine etkisi, . Yayımlanmamış Doktora Tezi. Erzurum: Atatürk Üniversitesi Eğitim Bilimleri Enstitüsü

Kardaş, M.N. (2013b) Birlikte öğrenme tekniğinin sınıf öğretmeni adaylarının yazılı anlatım alan bilgisi başarılarına etkisi. Mustafa Kemal University Journal of Social Sciences Institute, 10 (23), 81-96.

Kılıç, A. G. (2004). İşbirlikli öğrenme, okuduğunu anlama, strateji kullanımı ve tutum. Yayımlanmamış doktora tezi, Dokuz Eylül Üniversitesi Eğitim Bilimleri Enstitüsü, İzmir.

Maden, S. (2011a). Jigsaw I tekniğinin yazılı anlatım becerisi akademik başarısına etkisi. Educational Sciences: Theory \& Practice, 11(2), 901917.

Maden, S. (2011b). Takım oyun turnuva tekniğinin yazım kuralları ve işaretleri eğitiminde kullanımı. e-international journal of educational research, 2(3),52-67.

Maden, S., Şahin, A. ve Durukan, E. (2011). Türkçe öğretmenlerinin iş birlikli öğrenmeye yönelik tutumları. Erzincan Üniversitesi Sosyal Bilimler Enstitüsü Dergisi, 4(1), 155-174.

Melser, N.A., (1999). Gifted students and Cooperative learning: Study of Grouping strategies. Roeper Review, 21, 315-316

Özer, Ö. (1999). İş birlikli Öğrenme ve Öğrencilerin Güdülenmesi. Yayımlanmamış yüksek lisans tezi. Dokuz Eylül Üniversitesi Eğitim Bilimleri Enstitüsü, İzmir.

Özgiresun, A. (2005). İş birliğine dayalı öğrenmenin ikinci kademe fen bilgisi dersindeki öğrencilerin başarılarına, sosyal etkileşimlerine ve derse karşı tutumların etkisi. Yayımlanmamış Yüksek Lisans Tezi. Gazi Üniversitesi Eğitim Bilimleri Enstitüsü, Ankara.

Özkal, N. (2000). İş birlikli öğrenmenin sosyal bilgilere ilişkin benlik kavramı, tutumlar ve akademik basarı üzerindeki etkileri. Yayımlanmamış doktora tezi. Dokuz Eylül Üniversitesi Eğitim Bilimleri Enstitüsü, İzmir.

Pekaz, K. (2007). İlköğretim sekizinci sınıf yazılı anlatımlarındaki ses olayları, noktalama, imla hataları ve anlatım bozukluklarının düzeltilmesinde ipucu ve geribildirim teknikleri. Yayınlanmış yüksek lisans tezi, Abant İzzet Baysal Üniversitesi Sosyal Bilimler Enstitüsü, Bolu.

Richards, J. C. \& Rodgers, T. S. (2001). Approaches and methods language teaching. Cambridge University Press.

Saban, A. (2004). Öğrenme öğretme süreci yeni teori ve yaklaşımlar.

Salman, G. (2005). İş birlikli öğrenmenin hayat bilgisi dersinde sosyal beceriler erişi ve hatırda tutma üzerindeki etkileri. Yayımlanmamış 
Yüksek Lisans Tezi. Dokuz Eylül Üniversitesi Eğitim Bilimleri Enstitüsü.

Sarıtaş, E. (2002). İş birlikli ve geleneksel sınıflardaki başarılı ve başarısız problem çözücülerin kullandıkları öğrenme stratejileri, tutumları ve edim düzeyleri. Yayımlanmamış Doktora Tezi. Dokuz Eylül Üniversitesi Sosyal Bilimler Enstitüsü.

Senemoğlu, N. (2001). Gelişim öğrenme ve öğretim. Ankara: Gazi Kitabevi.

Sevim, O. ve Varışoğlu, B. (2014). Akademik çelişki tekniğinin Türkçe öğretmeni adaylarının kavram öğrenme başarılarına etkisi. Erzincan Üniversitesi Eğitim Fakültesi Dergisi, 16 (2), 229-247. DOI: $10.17556 /$ jef. 23848

Stevens, R.J. (2003). Student team learning and writing: a cooperative learning approach to middle school literacy instruction. Educational Research and Evaluation, 9(2), 137-160.

Sülün, Y., Tekin, B. ve Tekin, O. (2005). İlköğretim fen bilgisi dersinde maddelerin sınıflandırılması ve dönüşümleri konusunun kubaşık öğrenme yöntemiyle öğretiminin öğrenci başarısına etkisinin belirlenmesi. XIV. Ulusal Eğitim Bilimleri Kongresi (28-30 Eylül 2005). Pamukkale Üniversitesi, Denizli.

Syh-Jong, J. (2007). A study of students' construction of science knowledge: talk and writing in a collaborative group. Educational Researcher, 49(1); 65-81.

Şahin, A.(2010). Effects of jigsaw II technique on academic achievement. Educational Research and Reviews, 5(12), 777-787.

Şahin, E.Y., Maden, S., Kardaş, M.N. ve Şahin, A. (2011). Noktalama işaretlerinin öğretiminde grup araştırması tekniğinin öğrenci başarısına etkisi. Mustafa Kemal Üniversitesi Sosyal Bilimler Enstitüsü Dergisi, 8(15), 257-268.

Şahin, G. ve Topuzkanamış, E. (2008). Öğretmen adaylarının imla ve noktalama kurallarını uygulama düzeyleri üzerine bir araştırma: Balıkesir üniversitesi örneği. VII. Ulusal Sınıf Öğretmenliği Eğitimi Sempozyumu, Ankara.

Tarım, K. ve Artut, P.D. (2004). Anasınıfı öğrencilerine toplama ve çıkarama becerilerinin kazandırılmasında kubaşık öğrenme yönteminin uygulanması. 4. Uluslararası Okul Öncesi Kongresi. 30 Haziran/3 Temmuz 2004. İstanbul.

Temizkan, M. (2001). İlköğretim ikinci kademe öğrencilerinin yazılı anlatımlarının dil gelişimi bakımından incelenmesi. Yayınlanmamış yüksek lisans tezi. Mustafa Kemal Üniversitesi Sosyal Bilimler Enstitüsü, Hatay. 
Temizkan, M. (2008). Türkçe ve sınıf öğretmeni adaylarının yazılı anlatım çalışmalarını düzeltme ve değerlendirme durumları. Ahi Evran Üniversitesi Kırşehir Eğitim Fakültesi Dergisi (KEFAD), 9, 49-61.

Varışoğlu, B. (2016). İşbirlikli okuma ve yazma etkinliklerinin Türkçe öğrenen yabancı öğrencilerin dil kaygllarına etkisi. Elektronik Sosyal Bilimler Dergisi, 15(59).

Veenman, S., Van Benthum, N., Bootsma, D., Van Dieren, J., \& Van der Kemp, N. (2002). Cooperative learning and teacher education. Teaching and Teacher Education 18, 87-103

Yaman, B. (1999). Birleştirilmiş iş birlikli okuma ve yazma tekniğinin beşinci sınıf öğrencilerinin Türkçe dersinde okuduğunu anlamaya yönelik akademik başarıları ile Türkçe dersine ilişsin tutumları üzerindeki etkisi. Yayımlanmamış yüksek lisans tezi. Çukurova Üniversitesi Sosyal Bilimler Enstitüsü, Adana. 